\title{
Eksistensi Awig-Awig dalam Menjaga Harmonisasi \\ Desa Adat Tenganan Pegringsingan, Kabupaten Karangasem, Bali
}

Oleh:

Sumarjo ${ }^{1}$

\begin{abstract}
Abstrak
Tujuan penelitian ini adalah mendeskripsikan eksistensi awig-awig sebagai sumber hukum yang mampu menjaga, mengatur dan mengharmoniskan kehidupan masyarakat Desa adat Tenganan Pegringsingan Bali di tengah pusaran arus globalisasi. Penelitian ini menggunakan metode kualitatif. Pengumpulan data dilakukan melalui observasi, wawancara, dan studi dokumen. Data penelitian dianalisis dengan teknik analisis deskriptif kualitatif. Hasil penelitian menemukan bahwa awig-awig sebagai bentuk lokal wisdom yang diwariskan dari satu generasi ke generasi selanjutnya. Semua bentuk tata aturan kehidupan bersumber dari awig-awig. Eksistensi awig-awig mampu bersanding dengan pa radigma modernisasi. Tradisi perang pandan adalah wujud bagaimana awigawig mengatur pola kehidupan berdasarkan pakem. Perkembangan pariwisata yang kian masif, pada prakteknya, merespons masyarakat untuk ikut bagian memanfaatkan momen ini sebagai peluang untuk melanggengkan kebudayaan melalui tradisi menenun kain gringsing. Seiring perkembangannya, walaupun terdapat pergeseran makna dari ritual perang pandan dan kain gringsing, namun, semua bentuk pola aktivitas bermuara pada eksistensi awig-awig dalam menjaga keseimbangan sehingga tercipta harmonisasi hubungan masyarakat baik secara vertikal dan horizontal.
\end{abstract}

Kata kunci; Awig-Awig, Eksistensi, Harmonisasi, Lokal Wisdom, Modernisasi.

${ }_{1}^{1}$ Departemen Sosiologi, Fakultas Sosial dan Politik. Universitas Gadjah Mada 



\section{PENDAhuluan}

Bali menandai lahirnya modernisasi di indonesia bagian timur. Atmosfer modernisasi terus mencuat dan tidak heran, jika Bali memiliki daya tarik wisatawan nasional dan internasional karena keindahan alam dan keunikan culture (budaya). Berdasarkan hasil penelitian Utama (2016) yang berjudul keunikan budaya dan keindahan alam sebagai citra destinasi Bali menurut wisatawan Australia lanjut usia menghasilkan temuan bahwa eksistensi budaya dan alam Bali masih menjadi daya tarik bagi wisatawan lanjut usia. Hasil penelitian tersebut, melengkapi daftar kajian sebelumnya yang dilakukan oleh Suradnya (2005) dan Disparda (2012) (dalam Utama, 2016) yang menyimpulkan bahwa Bali merupakan destinasi tempat liburan yang cukup menarik bagi wisatawan mancanegara.

Berdasarkan catatan sejarah, di Bali dikenal dan telah mendapatkan pengakuan atas adanya kenyataan terdiri dari 2 Desa yaitu desa administratif atau desa dinas (kelurahan) dan desa adat. Pengertian desa dinas mengacu pada U.U. Nomor: 5 tahun 1979 tentang Pemerintahan Desa. Desa dalam pengertian ini mempuyai tugas antara lain, melaksanakan berbagai kegiatan organisasi pemerintahan atau kedinasan, sehingga dikenal dengan sebutan desa dinas atau desa administratif. Sedangkan, pada Perda Tingkat I Bali Nomor: 06/1986 tentang Kedudukan, Fungsi, dan Peranan Desa Adat sebagai Kesatuan
Masyarakat Hukum Adat dalam Prov. Daerah tingkat Bali memberi batasan tentang desa adat. Desa adat sebagai desa dresta adalah kesatuan masyarakat hukum adat di provinsi Bali yang mempunyai satu kesatuan tradisi dan tata krama pergaulan hidup masyarakat umat hindu secara turun temurun dalam ikatan kayangan tiga atau kayangan desa, yang mempunyai wilayah tertentu serta berhak mengurus rumah tangganya sendiri (Windia, 2010). Salah satu bentuk desa adat di Bali adalah Desa Tenganan Pengringsingan atau dikenal dengan sebutan Bali Aga karena masyarakatnya asli keturunan suku Bali, yang terletak di Kecamatan Manggis, Kabupaten Karangasem, Bali.

Tiap desa adat di Bali mempunyai aturan (tertulis maupun tidak terlulis) yang berlaku bagi semua masyarakat, bentuk aturan ini disebut dengan awig-awig. Pola kehidupan masyarakat Desa Tenganan sangat memperhatikan rumus keseimbangan. Pola hidup ini merujuk pada konsep Tri Hita Kirana berupa: Pertama Mengatur hubungan manusia dengan tuhan, kedua mengatur hubungan manusia dengan manusia, ketiga mengatur hubungan manusia dengan alam. Tri Hita Kirana mendasari awig-awig sehingga semua bentuk pola kehidupan telah memiliki aturan yang terhimpun dalam awig-awig. Berdasarkan hasil wawancara penulis, awigawig di Tenganan dibuat pada abad XI, pada awal desa ini mulai didirikan oleh warga 
Tenganan. Awig-awig itu dikenal dengan nama buku Sakti tebalnya sekitar 58 halaman dalam bahasa Bali, seiring perkembanganya terdapat beberapa pasal yang tidak berfungsi lagi.

Hadirnya modernisasi membawa konsekuensi pada perkembangan pariwisata. Kondisi demikian di pertegas dengan kehidupan desa adat pada era otonomi daerah atau globalisasi bukanya semakin ringan melainkan justru bertambah berat (Windia, 2010). Berdasarkan fakta di atas dapat dikatakan bahwa, Bali telah dikonsumsi publik begitupun dengan Desa Tenganan karena identitas culture (budaya) dan local wisdom (kearifan lokal) semakin menarik minat untuk diketahui dan dipahami oleh khalayak umum dalam memuaskan rasa keingintahuan diri ataupun untuk kajian akademik (pengembangan keilmuan).

Modernisasi yang berlangsung di Tenganan adalah sebuah proses transformasi identitas sosio-kultural. Transformasi lokal adalah bagian dari globalisasi sebagai perluasan secara lateral kaitanya sosial di berbagai ruang dan waktu (Giddens, 2005). Sifat terbuka dari penduduk Tenganan merupakan penegasan atas sifat dasar masyarakat yang dinamis. Transformasi lokal yang menandai gerak globalisasi semakin dinamis masuk di unit kehidupan warga Tenganan. Kondisi ini ditandai dengan perkembangan pariswisata yang semakin masif sekaligus peran awig-awig dalam memproteksi transformasi tersebut. Pariwisata sebagai salah satu "pintu" masuk budaya luar (global) yang membawa perubahan pada masyarakat ditandai antara lain dengan perkembangan dan peningkatkan kesejahteraan masyarakat dari ekonomi pariwisata. Perubahan tersebut berdampak pada eksistensi sosial, adat-istiadat, dan budaya masyarakat yang unik, dan sakral (Lodra, 2016).

Dilansir dari kompas.com Desa Tenganan adalah salah satu desa tertua sekaligus modern, di sini laki-laki dan perempuan sama, tak ada sistem kasta semua sama," kata Nyoman Suwita, pemandu sekaligus masyarakat Desa Tenganan Pegringsingan saat kunjungan familiarization trip The Anvaya Beach Resorts, Bali, Kamis (3/11/2016). Proses modernisasi yang semakin masif ternyata tidak menghilangkan identitas sosio-kultural Tenganan secara total, karena, proses menerima modernitas diiringi dengan penguatan awig-awig sehingga menandai bahwa Desa Tenganan semakin menarik untuk dikaji. Secara alami awig-awig memiliki kekuatan berlaku karena tumbuh dari bawah yaitu dari ketulusan masyarakat adat, ditaati karena dirasa sebagai suatu yang harus ada untuk kepentingan ketentraman dan keharmonisan masyarat adat dan sulit dipisahkan dari tingkah laku hidup dan kehidupan masyarakat adat (Artadi dalam Santoso 2012). 
Berdasarkan uraian di atas, penulis merumuskan bagaimana eksistensi awig-awig di tengah perkembangan modernisasi (sektor pariwisata), kaitannya untuk mengetahui harmonisasi dalam kerangka awig-awig. Penulis membatasi pembahasan pada pertama: modernisasi dan awig-awig, kedua: respons awig-awig terhadap pariwisata, ketiga: pariwisata sebuah komoditas. Poin ini menjadi dasar untuk membingkai bagaimana posisi dan peran awig-awig dalam menjaga harmonisasi kehidupan masyarakat Desa Adat Tenganan Pengringsingan.

\section{Teori AGIL Talcott Parsons}

Suatu sistem adalah suatu komleks kegiatan-kegiatan yang diarahkan kepada pemenuhan suatu kebutuhan atau kebutuhankebutuhan sistem itu, menggunakan definisi ini Parsons percaya bahwa ada empat imperatif fungsional yang perlu dibagi pada semua sistem, agar dapat lestari semua sistem harus melaksanakan keempat fungsi tersebut (Ritzer, 2012)

1. Adaptasi: suatu sistem harus mengatasi kebutuhan mendesak yang bersifat situasional eksternal. Sistem itu harus beradaptasi dengan lingkungannya dan mengadaptasikan lingkunganya denga kebutuhan-kebutuhan.

2. Pencapaian tujuan: suatu sistem harus mendefinisikan dan mencapai tujuan utamanya
3. Integrasi: suatu sistem harus mengatur antarhubungan bagian-bagian dari komponennya, ia juga harus mengelola hubungan diantara tiga imperatif fungsional lainnya $(A, G, L)$

4. Latensi (Pemeliharaan pola): suatu sistem harus menyediakan, memelihara, dan memperbaiki baik motivasi para individu maupun pola-pola budaya yang menciptakan dan menopang motivasi itu.

Konsep Budaya sebagai Sistem Pengetahuan

Menurut Ward Goodenough (dalam Keesing) kebudayaan suatu masyarakat terdiri atas segala sesuatu yang harus diketahui atau dipercayai seseorang agar dia dapat berperilaku dalam cara yang dapat diterima oleh anggota-anggota masyarakat tersebut. Budaya bukanlah suatu fenomena material: dia tidak berdiri atas benda-benda, manusia, tingkah laku atau emosi-emosi. Budaya lebih merupakan organisasi dari hal-hal tersebut. Budaya adalah bentuk hal-hal yang ada dalam pikiran (mind) manusia, model-model yang dipunyai manusia untuk menerima, menghubungkan, dan kemudian menafsirkan penomena material di atas $(32, \mathrm{hlm} .167)$

Kebudayaan terdiri atas pedomanpedoman (1) untuk menentukan apa, (2) untuk menentukan apa yang dapat menjadi, (3) untuk menentukan apa yang dirasakan seseorang tentang hal itu, (3) untuk menentukan 
bagaimana berbuat terhadap hal itu, (4) untuk menentukan bagaimana caranya menghadapi hal itu (33, hlm. 522)

\section{METODOLOGI}

Penelitian ini menggunakan pendekatan kualitatif agar dapat mempelajari, menerangkan, atau menginterpretasikan suatu fenomena sosial. Bogdan dan Taylor (Moleong, 2014) menjelaskan bahwa metode penelitian kualitatif digunakan sebagai prosedur penelitian yang menghasilkan data deksriptif berupa kata-kata tertulis atau lisan dari orang-orang dan perilaku yang dapat diamati.

Penelitian dilakukan di Desa Adat Tenganan Pengringsingan yang dikenal dengan sebutan Bali Aga yang penduduk Bali Aga masih mempertahankan awig-awig sebagai salah satu pedoman dalam berprilaku. Desa Adat Tenganan Pegringsingan berada di bagian timur Pulau Bali yang berjarak sekitar $67 \mathrm{~km}$ dari Denpasar. Teknik pengumpulan data dilakukan dengan menggunakan teknik: (1) observasi langsung yang bersifat nonpartisipasi, (2) wawancara mendalam (indepth interview) terhadap beberapa informan, (3) studi pustaka atau membandingkan data dengan sumber-sumber tertulis, dan (4) dokumentasi.

Menurut Bogdan (Sugiyono, 2012) analisis data adalah proses mencari dan menyusun data secara sistematis data yang diperoleh dari hasil wawancara, catatan lapangan dan dokumentasi dengan cara mengelompokkan data sesuai dengan kategori kemudian membuat kesimpulan sehingga mudah dipahami oleh diri sendiri maupun orang lain. Analisis data yang digunakan adalah analisis data kualitatif deskriptif dengan prosesnya meliputi tiga tahapan yaitu pengumpulan data secara keseluruhan yang diperoleh setelah penelitian, kemudian data tersebut diklasifikasikan sesuai dengan hasil pengumpulan data atau berdasarkan rumusan masalah, selanjutnya data proses penelitian tersebut diverifikasi yaitu pembuktian kebenarannya agar mudah dipahami. Untuk pengujian atau pemeriksaan derajat kepercayaan data (keabsahan data), penelitian ini menggunakan teknik triangulasi sumber yaitu dengan cara pemeriksaan data hasil penelitian dengan membandingkannya dengan data dari sumber lainnya.

\section{HASIL}

Secara sosiologis, interaksi antara individu dengan individu maupun individu dengan kelompok menengarai proses berlangsungnya kehidupan sosial. Bagi warga Tenganan prinsip interkasi tersebut harus mengarah pada keseimbangan. Prinsip keseimbangan merupakan pola bagimana harmonisasi tercipta melalui hubungan antara manusia dengan manusia. Awig-awig sebagai konsensus yang dipahami, diyakini, dan ditaati membentuk pola bagaimana menjaga, 
memelihara dan melanjutkan peradaban yang harmonis pada tiap generasi. Potret awig-awig membingkai hubungan antara manusia dengan manusia ditengah perkembangan modernisasi yang semakin masif.

\section{a. Modernisasi dan Awig-Awig}

Paradigma modernisasi pada umumnya sulit untuk bisa bersanding dengan eksistensi masyarakat lokal. Umumnya, modernisasi dianggap proses perubahan struktur yang membawa pengaruh negatif. Namun, di Desa Tenganan terdapat corak menarik dari hadirnya paradigma modernisasi yang mampu bersanding dengan eksistensi lokalitas Bali Aga. Secara normatif, konsep awig-awig merupakan sebuah aturan yang mampu membuat masyarakat bertindak sesuai pakem yang telah disepakati. Kondisi demikian menyatakan bahwa masyarakat Tenganan sangat kuat dalam menjaga adat, teguh menjaga budaya, tetapi juga menjadi bagian dari arus perubahan modernisasi (Aryandri, 2010). Ritual perang pandan, tradisi menenun kain gringsing, pemanfaatan hutan merupakan konsep manusia menjaga hubungan dengan manusia dalam kerangka realitas Tri Hita Kirana.

Dari hasil penelitian Suwardani (2015) Bali diperhadapkan pada fenomena paradoks, yakni berdiri pada pijakan yang berbeda. Kaki kanan terikat pada kekuatan tradisi, sedangkan kaki kiri menganut sistem nilai dari luar atau nilai-nilai modern. Namun, paradoks ini tidak sepenuhnya sama dialami oleh seluruh daerah Bali. Kondisi berbeda terjadi di Desa Tenganan, proses menjaga budaya yang terintegrasi dengan arus modernisasi menandai bahwa kedua paradigma tersebut dapat bersanding dan menciptakan peluang positif bagi masyarakat Tenganan.

Dalam kerangka Fungsionalisme struktural Parsons, hadirnya modernisasi di Desa Tenganan telah menandai peluang bagi masyarakat untuk mengambil peran melalui pariwisata. Awig-awig dihadapkan pada posisi untuk beradaptasi dengan perkembangan pariwisata. Gold dari proses ini adalah kedua paradigma ini berada pada pola saling mempengaruhi antara modernitas dan tradisional. Proses integrasi merupakan cara dari sistem mengatur antarhubungan bagianbagian dari komponennya. Awig-awig tetap menjadi pedoman ditengah pariwisata yang kian masif. Pedoman ini mengatur tentang aturan, anjuran dan larangan terkait dengan usaha memelihara keseimbangan akibat dari pengaruh modernisasi dengan cara menegakkan pasal dari tiap awig-awig agar mampu menjaga harmonisasi kehidupan jika terdapat pelanggaran yang terjadi diluar batas pakem awig-awig.

Paradigma modernitas hadir di Desa Tenganan ditandai dengan masifnya pariwisata. Akan tetapi, proses ini justru 
menciptakan peluang bagi masyarakat Tenganan untuk menjadi bagian dari pariwisata melalui tradisi menenun kain gringsing.

\section{b. Respons Awig-Awig terhadap Perkembangan Pariwisata}

\section{Ritual Perang Pandan}

Ritual perang pandan merupakan ritual sakral di Desa Tenganan sebagai wujud persembahan kepada Dewa Indra. Ritual ini juga diyakini akan membawa kesuburan di tanah Tenganan. Dilansir dari kompas.com Perang pandan dilaksanakan setiap bulan kelima atau sasih kalima dalam penanggalan Desa Adat Tenganan, ritual perang pandan berlangsung kurang lebih selama dua hari berturut-turut, upacara ritual ini dilakukan setiap satu tahun sekali, ujar Sukadnyana. Ritual perang pandan bukanlah atraksi yang akan berakhir kalah atau menang bagi para pelaganya. Atraksi ini adalah ritual pemujaan masyarakat Tenganan kepada Dewa Indra, sang dewa perang dihormati dengan darah sehingga atraksi perang pandan dilakukan tanpa rasa dendam (Aryandri, 2010).

Pada prosesnya ritual perang pandang melibatkan laki-laki dan perempuan walaupun peran yang mereka miliki berbeda. Proses perang pandan dilakukan oleh laki-laki tenganan dengan cara berhadapan saling berpasangan untuk bertarung. Proses pertarungan mempertontonkan aksi saling pukul memukul, pertarungan berakhir ketika salah satu telah terjatuh atau dihentikan oleh juru pisah. Sedangkan, perempuan dihadirkan untuk memberikan semangat petarung dan pada akhir kegiatan perang pandan para perempuan yang terdiri dari remaja putri hingga anak-anak menampilkan tarian rejang.

Pandangan masyarakat tenganan meyakini bahwa ritual perang pandan merupakan cara untuk menjaga keseimbangan. Proses ritual didasarkan atas keyakinan warga Tenganan pada Dewa Indra. Bentuk keyakinan ini bermuara pada harmonisasi setelah proses perang pandan berlangsung. Berdasarkan konsep kebudayaan menurut Ward Goodenough berupa: pertama menentukan bagaimana berbuat yaitu ritual perang pandan merupakan cara warga tenganan mempersembahkan penghormatan atas keberadaan Dewa Indra (Dewa perang). Kedua, menentukan apa yang dirasakan yaitu hasil yang diharapkan setelah ritual perang pandan. Hasil tersebut merujuk pada pola keseimbangan. Bagi orang tenganan, Dewa Indra pernah hidup di masa lampau dan sampai saat ini masih diyakini keberadaanya, melalui ritual masyarakat memberikan kehormatan kepada kekuatan yang memberikan penjagaan dan kedamaian (Aryandari 2010).

Bentuk ritual perang pandan diyakini membawa kedamaian. Tradisi ini telah terinternalisasi pada seluruh warga tenganan, 
antara mitos ataupun keyakinan, namun, perang pandan selalu populer pada tiap generasi karena ritual perang pandan dilaksanakan tiap tahun dan melibatkan warga tenganan.

\section{Posisi Awig-Awig dalam Ritual Perang Pandan}

Tradisi perang pandan selain menjadi bagian upacara adat warga Tenganan, tradisi ini juga menjadi bagian dari upacara pariwisata dunia (Aryandari, 2010). Kondisi ini menegaskan bahwa kebudayaan mampu mempercepat laju perkembangan pariwisata di Tenganan. Terlepas dari praktek ritual yang berlangsung, posisi awig-awig menjadi penting untuk diketahui dalam ritual perang pandan.

Perjalanan awig-awig sebagai aturan adat sudah sepantasnya selalu tumbuh, berkembang selaras, dan menyesuaikan diri dengan masa dan tingkat kemanfaatan untuk kepentingan masyarakat adat (Santoso dkk, 2012). Ritual perang pandang merupakan tradisi yang dilakukan hanya setahun sekali. Ritual tersebut telah menjadi bagian dari upacara pariwisata dunia, kondisi ini menegaskan bahwa awig-awig mengikuti alur bagimana warga tenganan bisa berdiri di pondasi modernisasi. Perkembangan pariwisata di Tenganan tidak merespons warga tenganan untuk melanggar pakem awig-awig misalnya dengan mengadakan ritual perang pandan sebagai komoditas yang dilaksanakan tiap bulan.

Merujuk konsep kebudayaan menurut Ward Goodenough kebudayaan diartikan suatu masyarakat terdiri atas segala sesuatu yang harus diketahui atau dipercayai seseorang agar dia dapat berperilaku dalam cara yang dapat diterima oleh anggotaanggota masyarakat tersebut. Ritual perang pandan dipahami sebagai suatu nilai sakral yang mampu menjaga keseimbangan di kehidupan. Proses mengetahui ataupun mempercayai makna perang pandan adalah sebuah proses sosialisasi dan internalisasi nilai dan makna ritual perang pandan dari tiap generasi. Pemahaman tersebut membentuk prilaku masyarakat yang menjadi bagian dari komunitas dan diterimah sebagai anggota komunitas. Disisi lain, untuk melihat posisi awig-awig, penulis membandingkan tradisi tenganan dan kesenian tari Barong,

Berdasarkan hasil riset berjudul komodifikasi tari barong di pulau Bali seni berdasarkan karakter pariwisata (2016) menemukan bahwa tari Barong yang merupakan salah satu tarian tradisional Bali yang bernilai religius atau sakral telah mengalami pergeseran dari induknya atau keasliannya. Kini tari Barong menjadi pertunjukan tari wisata yang bersifat terbuka setelah melalui proses pengemasan untuk kepentingan industri pariwisata. Proses 
pengemasan yang dimaksud adalah profanisasi yaitu tari yang dikemas sedemikian rupa sehingga lebih bersifat duniawi, bertujuan menghibur (Dewi, 2016). Hasil temuan ini menegaskan lemahnya posisi awig-awig. Namun, tidak demikian dengan awig-awig Desa Tenganan. Ritual perang pandan masih mendapatkan proteksi yang tegas dari awig-awig sehingga walaupun pesatnya perkembangan pariwisata namun perang pandan masih berada pada pakem yang sesuai dengan awig-awig. Perbedaan aturan awig-awig pada tiap desa adat membawa konsekuensi pada sikap masyarakat untuk menaati atau melanggar aturan di awig-awig. Prinsip keseimbangan adalah kata kunci yang bermuara pada keyakinan warga tenganan untuk patuh dan menerapkan awig-awig pada tiap praktek kehidupan.

Kedekatan masyarakat adat dengan lingkungan telah membuat setiap bentuk kegiatan pembangunan tetap mengacu pada tata nilai, norma, tradisi, ke percayaan, serta kebudyaan aslinya yang kemudian melahirkan suatu kearifan lokal yang menjadi landasan (Santoso dkk, 2012). Pembangunan pariwisata yang menampilkan ritual perang pandan sebagai konsumsi publik tidak terlepas dari peran awig-awig. Proses ritual yang masih mempertimbangkan nilai, menjaga keutuhan tradisi merupakan wujud kepercayaan terhadap awig-awig. Pada dasarnya, eksistensi awig-awig terlihat dari bentuk keyakinan masyarakat. Jika praktek awig-awig di terapkan sesuai pakem, maka eksistensi awig-awig masyarakat akan menciptakan harmonisasi.

\section{c. Pariwisata sebuah Komoditas}

Ritual perang pandan telah menjadi konsumsi publik. Konsumsi untuk sebuah rekreasi ataupun untuk di teliti (kajian akademik). Melalui konsumsi publik, ritual perang pandan menandai bahwa, tenganan memiliki 2 wajah yaitu tradisional dan modern. Kondisi demikian menegaskan bahwa, pariwisata ada karena kebudayaan bukan kebudayaan ada karena pariwisata, ungkap I ketut Sudiastika (kepala Desa Adat Tenganan Pengringsingan). Hadirnya pariwisata di Tenganan diyakini tidak akan mengikis identitas Tenganan, justru hadirnya pariwisata memberikan keuntungan karena dana ritual yang sebelumnya dibebankan pada warga tenganan kini menggunakan dana hasil pariwisata. Lalu, perkembangan pariwisata yang kian masif di tenganan memunculkan pertanyaan bagaimana peradaban tenganan selanjutnya, karena pariwisata telah menandai bagaimana budaya mampu menghadirkan pundi-pundi rupiah bagi warga tenganan. Hadirnya pundi-pundi rupiah telah merubah persepsi masyarakat misalnya pergeseran makna kain gringsing. 
Gringsing merupakan warisan budaya. Kegiatan menenun merupakan kreativitas yang dimiliki dan diwariskan secara turunmenurun di Tenganan. Kain gringsing berasal dari kata "gring" (sakit) dan "sing" (tidak) dari pengetian tersebut melahirkan keyakinan bahwa kain gringsing dapat menyembuhkan penyakit. Menurut pandangan orang tenganan, gringsing mengandung nilai magis, gringsing dikenal sebagai tenun ikat ganda dan motif gringsing membentuk tanda tambah yang menggambarkan filosofi hidup orang tenganan yaitu keseimbangan. Filosofi tersebut menjadi sebuah pertanyaan ketika kain gringsing digadaikan karena perkembangan pariwisata yang kian masif. Gringsing menjadi komoditas bernilai jual tinggi. Kain yang dahulu hanya digunakan warga tenganan untuk ritual kini telah menjadi komoditas yang membentuk kelas berdasarkan harga gringsing. Pada dasarnya, kain gringsing hanya terdiri dari 3 warna yaitu merah mencerminkan api (dibuat dari kulit mengkudu), putih mencerminkan air (dibuat minyak kemidiri), dan hitam mencerminkan angin (dibuat dari daun talu). Filosofis tiga komponen warna tersebut adalah upaya dalam menjaga keseimbangan, namun, modifikasi kain gringsing menandai bahwa gringsing telah mengikuti perkembangan dunia fashion.

Perubahan pemaknaan gringsing adalah resiko dari sifat dasar masyarakat yang dinamis. Masyarakat tidak didefinisikan dengan sifat statis, gerak dinamis adalah pola yang menandai masyarakat semakin mengalami kemajuan atau kemunduran di tiap peradaban. Fakta di atas menandai bahwa peran awig-awig menjadi begitu penting dalam proses menjaga dan melanjutkan peradaban agar identitas tenganan tidak kabur di tengah masifnya pariwisata. Namun, perlu di ingat adalah tradisi menenun yang berkembang di Tenganan adalah cara mengingat, memproduksi pengetahuan, sekaligus memahami nilai dan makna dari sebuah hasil kebudayaan. Proses ini menandai bahwa, gringsing telah mendapatkan posisi dalam masyarakat dan diterimah pada tiap peradaban.

Dilansir dari Net Bali pada peringati hari perempuan internasional dan hari kartini sebuah pameran foto tentang kehidupan wanita desa tenganan pegringsingan digelar di seminyak Bali, berbagai foto dan kain tenun gringsing yang harganya hingga jutaan rupiah menjadi objek dari pameran ini. Momen peringati hari perempuan internasional dan hari kartini adalah sebuah cara yang dilakukan untuk mengenalkan kain gringsing pada masyarakat luas.

Budaya Bali memiliki identitas yang jelas yaitu budaya ekspresif yang termanifestasi secara konfiguratif yang mencakup nilai-nilai dasar yang dominan, seperti nilai religius, nilai estetika, nilai 
solidaritas, nilai harmonis, dan nilai keseimbangan (Geriya dalam Suwardani, 2015). Kejelasan budaya ini, menempatkan posisi awig-awig sebagai upaya menyesuaikan dan adaptasi terhadap perubahan. Awig-awig diyakini sebagai benteng akhir dari ketahanan budaya sehingga pergeseran makna dari kain gringsing adalah upaya warga tenganan untuk melanggengkan dan mewariskan tradisi menenun pada tiap generasi. Komoditas kain gringsing adalah cara merespons modernisasi sebagai pengaruh yang positif. Pariwisata adalah sebuah wadah, dimana tradisi menenun diwariskan pada tiap generasi. Bagus (dalam Suwardani, 2015) juga menegaskan, bahwa meskipun masyarakat Bali telah mengalami "pergesekan budaya" yang datang dari timur dan barat, sehingga menimbulkan adanya perubahan-perubahan, namun pada hakekatnya perubahan yang ditimbulkan akibat pertemuan budaya tersebut belum begitu berarti, karena masyarakat Bali masih bercorak kolektif, komunal dan ritualistik. Pergesekan budaya yang terjadi di Tenganan direspons positif oleh warga desa Tenganan. Respons ini bermuara pada upaya warga Tenganan dalam melanggengkan tradisi menenun yang menghasilkan pundi-pundi rupiah sekaligus meningkatkan kreativitas sebagai bentuk produksi dan investasi pengetahuan pada tiap peradaban dalam kerangka awig-awig.

\section{KESIMPULAN}

Hasil penelitian menemukan bahwa awig-awig diwariskan dari satu generasi kegenerasi selanjutnya melalui respons karena hadirnya pariwisata. Semua bentuk tata aturan kehidupan bersumber dari awig-awig. Masyarakat Tenganan meyakini bahwa awigawig mampu menjaga kehidupan masyarakat agar keseimbangan tetap terjaga.

1. Eksistensi awig-awig mampu bersanding dengan paradigma modernisasi. Perkembangan pariwisata adalah wujud dari pengaruh modernisasi. Perkembangan pariwisata tersebut, tidak sepenuhnya mengikis identitas kultural masyarakat tenganan, namun perkembangan pariwisata mampu menciptakan peluang dalam pola menjaga harmonisasi.

2. Tradisi perang pandan merupakan bentuk persembahkan kepada Dewa Indra (Dewa Perang). Praktek tradisi ini melibatkan laki-laki dan perempuan. Tradisi ini dilaksanakan setahun sekali dan menjadi momentum ritual adat sekaligus upacara ritual dunia (komoditas). Melalui ritual perang pandan, posisi dan peran awigawig sangat pakem, karena masyarakat Tenganan masih mempertahankan pakem kesakralan ritual dengan tidak menggadaikan ritual perang pandan sebagai komoditas yang berlangsung setiap bulan. 
3. Perkembangan pariwisata yang kian masif, pada prakteknya, merespons masyarakat untuk ikut bagian memanfaatkan momen ini sebagai peluang untuk melanggengkan kebudayaan melalui tradisi menenun kain gringsing. Walaupun terdapat pergeseran makna kain gringsing, namun aktivitas menenun dimaknai sebagai pola melanggengkan tradisi.

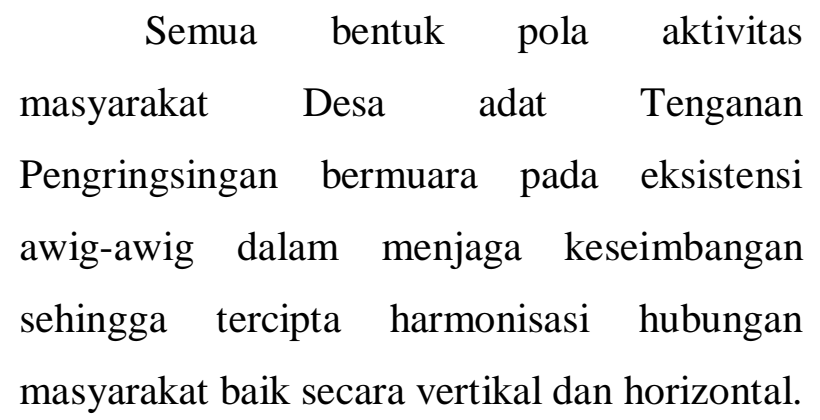

\section{DAFTAR PUSTAKA}

Aryandari, Citra. 2010. “Gringsing” Jalinan Estetika-Mitos Ritus Perang Pandan. Jurnal Resital, Vol. 11 No. 2

Dewi, Anggraeni Purnama. 2016. Komodifikasi Tari Barong di Pulau Bali Seni Berdasarkan Karakter Pariwisata. Jurnal Panggung Vol. 26 No.3

Giddens, Anthony. 2005. Konsekuensi-Konsekuensi Modernitas. Yogyakarta: Kreasi Wacana

Lodra, I Nyoman. 2016. Komodifikasi Makna Tenun Gringsing sebagai “Soft Power” Menghadapi Budaya Global. Jurnal kajian Bali Vol.06 No.01

Moleong, L. 2014. Metodologi Penelitian Kualitatif. Bandung: PT Remaja Posdakarya

Ritzer, George. 2012. Teori Sosiologi (Dari Sosiologi Klasik sampai Perkembangan Terakhir Postmodern).Yogyakarta: Pustaka Pelajar

Santoso, dkk. 2012. Desa Adat Tenganan Pengringsiangan dalam Pengelolaan Hutan di Desa Tenganan, Kecamatan Manggis, Karangasem, Bali. Jurnal Resital Vol. 11 No.2

Sugiyono. 2012. Metode Penelitian Pendidikan (Pendekatan Kuantitatif, Kualitatif, dan $R \& D$ ). Bandung: Penerbit Alfabeta

Suwardani, Ni Putu. 2015. Pewarisan Nilai-Nilai Kearifan Lokal untuk Memproteksi Masyarakat Bali dari Dampak Negatif Globalisasi. Jurnal Kajian Bali Vol. 05, No. 02

Utama, I Gusti Bagus Rai. 2016. Keunikan Budaya dan Keindahan Alam sebagai Citra Destinasi Bali menurut Wisatawan Australia Lanjut Usia. Jurnal Kajian Bali Vol. 06 No. 01

Windia, Wayan P. 2010. Bali Mawacara Kesatuan Awig-Awig, Hukum dan Pemerintahan di Bali. Denpasar: Udayana University Press 


\section{Sumber Media Online}

http://travel.kompas.com/read/2016/11/08/063800827/menjumpai.sisi.lain.bali.di.desa. adat.tenganan (diakses pada 23 Oktober 2017)

https://www.youtube.com/watch?v=bcmhED7Jm6I (diakses pada 23 Oktober 2017)

http://regional.liputan6.com/read/2992498/perang-pandan-tradisi-tahunan-menghormati-dewa-indra (diakses pada 23 Oktober 2017)

Keesing, Roger M. Teori-teori tentang Budaya tersedia di http://journal.ui.ac.id/index/jai/article/download/3313/2600 (diakses pada 23 Oktober 2017) 